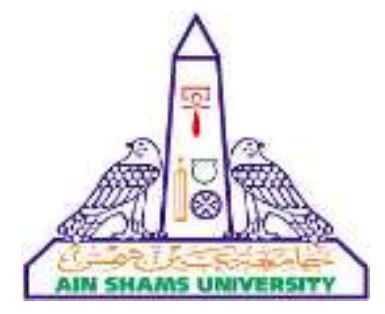

Ain Shams University

Faculty of Education

Reading \& Knowledge Magazine

\title{
An EFL Program for Enhancing Textual Cohesion and Coherence in Promoting Reading and Writing
}

\author{
Prepared by: \\ Hussein Maghawry Hussein \\ A PhD Candidate \\ Department of Curriculum and EFL Instruction \\ Faculty of Education - Ain Shams University
}

\section{Supervised by}

Dr.

Magdy Mahdy Aly

Professor of Curriculum

and EFL Instruction

Faculty of Education

Ain Shams University
Dr.

\author{
Badr Abdel Fattah Abdel Kafy \\ Lecturer of Curriculum \\ and EFL Instruction \\ Faculty of Education \\ Ain Shams University
}




\begin{abstract}
A Dissertation Submitted in Partial Fulfillments of the Requirements for the $\mathrm{PhD}$ Degree in Education

(Department of Curriculum \& Instruction: TEFL)
\end{abstract}

The present study aimed at enhancing third-year secondary school students' reading comprehension and expository writing skills through expanding their knowledge of textual cohesion and coherence. It adopted the qusai-experimental pre-post test one group design. Participants of the study comprised 39 students at Manfalut Secondary School for Girls, Assiut Governorate. Through a proposed program, they received training on identifying and using various textual features, with particular focus on text structure and textual cohesion and coherence. Instruments of the study included: a reading comprehension skills checklist, an expository writing skills checklist, a reading and writing skills pre-post test, a software tool for corpus analysis, a student satisfaction questionnaire and a reflection log. Study results yielded statistically significant differences at 0.01 level between the mean scores of the pre and post tests. The results indicated that the program had a large positive effect on the participants' overall skills in reading comprehension and expository writing. In addition, a written discourse analysis of participants' essays in the pre-test revealed that many third-year secondary school students lacked sufficient knowledge of textual cohesion and coherence and faced various difficulties in using grammatical and lexical cohesive devices. The satisfaction questionnaire indicated that the majority of the students benefited from the program, though some believed that it was difficult. It was concluded that teaching textual cohesion and coherence enhances students' reading comprehension and expository writing skills. Pedagogical implications suggest embedding the teaching of textual cohesion and coherence into EFL course books and tutorial materials, especially in the secondary stage.

Key Words: reading comprehension, expository writing, textual cohesion, textual coherence, written discourse analysis 


\section{Introduction}

Enhancing students' English language skills has always provoked exasperated but enthusiastic inquiry within the global research community. Many researchers focussed on improving students' reading comprehension skills and writing performance because the skills are the key to personal, professional and comprehensive growth in today's world (Cohen \& Cowen, 2007).

Firstly, reading is "an amazing capacity that allows people in different physical locations and eras to communicate ideas, grand and mundane, to one another" (Hudson, 2007, p. 7). People use it on a daily basis to interact with written text of different genres, such as signs, advertisements, textbooks, emails and social media (Cain, 2010), and create meaning on their own.

Creating meaning from text refers to comprehension which lies at the heart of reading. that reading comprehension is the process of acquiring, confirming and creating meaning out of a text (Snow, 2002). However, for texts to be clear, they should exhibit cohesion and coherence. (Halliday \& Hasan, 1976).

Cohesion expresses semantic relations which exist in a text. It "occurs where the interpretation of some element in the discourse is dependent on that of another" (Halliday \& Hasan, 1976, p. 4). As for coherence, it is the logical unity between different segments of language, which distinguishes it from randomly-assembled sentences (Huang, 2012).

Secondly, writing is a fundamental "vehicle for communication and a skill mandated in all aspects of life" (Caswell \& Mahler, 2004, p. 3). Yet, it is a difficult process for first and second language learners who should employ the lower-level skills of writing such as spelling, and the higher-level skills of 
planning and organization, to make their texts readable, cohesive and coherent (Richards \& Renandya, 2002).

At the global level, almost $30 \%$ of students in the United Kingdom and the United States of America face significant difficulties to comprehend simple daily reading tasks (Looney, 2008). EFL students face similar challenges (David \& Govindasamy, 2003), and Arab secondary-school students are no exception (Alkhawaldeh, 2012). Similarly, students are unable to create cohesive and coherent written texts (Ghasemi, 2013).

A possible cause of students' low performance in reading comprehension tasks and in writing essays is their poor knowledge of textual cohesion and coherence. This inadequate knowledge hinders them from making sense of reading texts (Grabe, 2009). In a reading comprehension task, students may be able to recognize words separately, and understand sentences one by one. Yet, they may be unable to link the ideas introduced in a whole text as a result of their limited knowledge of textual cohesion and coherence. Also, lack of such knowledge makes it a burdensome task for students to to compose cohesive and coherent written essays (Rassouli \& Abbasvandi, 2013).

The main reason accounting for students' poor knowledge of textual cohesion and coherence is that EFL reading and writing do not usually cover such concepts. As a result, EFL instructors ignore teaching these valuable textual features to students (Cho \& Shin, 2014; Ghasemi, 2013).

Teaching phonemes and words is not enough to enhance comprehension skills (Almasi \& Fullerton, 2012). Graesser, McNamara and Louwerse (2003) believed that just as there are reading programs that promote phonemic awareness, there should be special programs that emphasize coherence awareness. They suggested a cottage industry of teaching material, computer 
software and teacher training workshops that identify the various types of coherence relations.

In Iran, Sabet, Khodabandehlou and Jahandar (2013) found that instructing cohesive devices was effective in helping students perform better in reading comprehension tests. Likewise, in Thailand by Tangkiengsirisin (2010), EFL students received instruction on textual cohesion in writing classes. Results revealed significant improvement of the subjects in writing cohesive.

In the current study, the researcher proposed a special EFL program for enhancing third-year secondary students' knowledge of textual cohesion and coherence. A trained EFL teacher delivered the program to help the participants perform better in constructing meaning from reading comprehension texts and in writing more cohesive and coherent expository essays.

\section{Context of the Problem and Pilot Study}

In Egypt, research indicated that secondary school students faced problems in reading comprehension and writing. El-Koumy (2006) found that $85 \%$ of students experienced difficulty in understanding cohesive relations among words, sentences, paragraphs and the whole text. Likewise, second-year secondary students' essays reflected poor competence in textual cohesion and coherence (El-Deen, 2014).

\section{Statement of the Problem}

Third-year secondary school students face problems in constructing meaning from reading comprehension texts and in writing cohesive and coherent essays. 


\section{Research Questions}

1-How is the suggested program effective in promoting third-year secondary school students' reading comprehension and writing skills?

2-How is the suggested program effective in promoting cohesion within third-year secondary school students' expository writing?

3-How is the suggested program effective in promoting coherence within third-year secondary school students' expository writing?

4-What are the types of cohesive devices employed by third-year secondary school students in writing expositions?

5-How frequent is each type of cohesive devices used by the students in writing expositions?

6-What are the problems that the students face in employing cohesive devices in writing expositions?

\section{Purpose of the Study}

The purpose of the study is to investigate the effectiveness of a suggested program for enhancing EFL students' knowledge of textual cohesion and coherence in developing third-year secondary school students' reading comprehension skills and in writing expositions.

\section{Literature Review}

A text is not merely a collection of sentences, nor is it just a large grammatical unit that looks like a large sentence. Rather, a text is best viewed of as a semantic entity (Halliday \& Hasan, 1976). The concept of texture expresses the relationships and unity that exist between and among the sentences of a text. They distinguish a text from non-text.

Cohesion refers to the semantic relations that exist between an item in the text and another item which is essential to the explanation of that text. 
According to Halliday and Hasan (1976), one item assumes the existence of the other, as one cannot be sensibly decoded except by referring to the other. It is categorized into two types: grammatical and lexical. The grammatical type is created by particular grammatical devices used to establish relations among sentences, whereas the lexical one is generated through the structure of vocabulary by relating words in terms of their meaning.

Coherence is viewed as a multidimensional concept which covers a range of discourse features. Text-based approaches argue that coherence is an intrinsic property of texts that cohere if they contain particular features. According to Richards and Schmidt (2013), coherence in written texts refers to the relevance and organization of ideas in a way that makes them clear and comprehensible to the reader. To Mather et al. (2009), text coherence refers to both maintaining the topic and introducing ideas in a sequenced and organized way.

I. Lee (2002a) examined and summarized scholars' various definitions and description of textual coherence and presented five aspects of this concept, as shown in Table (1).

\section{Table 1}

Five Aspects of Textual Coherence

\begin{tabular}{|l|l|}
\hline Aspect & Explanation \\
\hline Cohesion & $\begin{array}{l}\text { Text connectivity at the surface level created by adopting } \\
\text { cohesive devices }\end{array}$ \\
\hline $\begin{array}{l}\text { Local } \\
\text { Coherence }\end{array}$ & $\begin{array}{l}\text { Connectivity of text content established through relations } \\
\text { between propositions and overall discourse }\end{array}$ \\
\hline $\begin{array}{l}\text { Global } \\
\text { Coherence }\end{array}$ & $\begin{array}{l}\text { A macrostructure of text with a characteristic pattern } \\
\text { which is appropriate to its communicative purpose and } \\
\text { context }\end{array}$ \\
\hline $\begin{array}{l}\text { Information } \\
\text { Distribution }\end{array}$ & $\begin{array}{l}\text { Global organization of information in text which } \\
\text { contributes to topical development }\end{array}$ \\
\hline $\begin{array}{l}\text { Meta- } \\
\text { discourse }\end{array}$ & $\begin{array}{l}\text { A set of textual guidelines and expressions that clarifies } \\
\text { writers' attitudes and organization of information }\end{array}$ \\
\hline
\end{tabular}

Based on I. Lee (2002a) 
As illustrated in Table (1), the five aspects of textual coherence identified by I. Lee (2002a) are: cohesion, local coherence, global coherence, information distribution and meta-discourse.

According to I. Lee (2002a), text linguists have broadened the conceptualization of text coherence by including cohesion between sentences and paragraphs as an essential aspect of textual coherence. They affirm that writers can use grammatical and lexical cohesive devices to connect ideas in texts to create textuality, and that the five previously-mentioned cohesive devices; reference, substitution, ellipsis, conjunction and lexical cohesion, serve to make explicit the underlying connectivity of text.

Local coherence is sometimes referred to as coherence at the micro-level or micro-structure and it indicates the interrelatedness between adjacent segments of text (Strazny, 2013). It "occurs within small portions of texts" (Kucan \& Palincsar, 2013, p. 6) because it is created when adjacent clauses in text can be connected logically (Graesser et al., 2003).

Global coherence can be created when each paragraph has a unifying idea which if listed in order should show the gist or theme of the text. Such theme is often made explicit in the title, introduction, thesis statement, topic sentences and summary (Dijk, as cited in Achili, 2007).Through global coherence, or macrostructure, writers and readers realize the relationship between sentences in a text and how they contribute to its overall coherence (Hoey, as cited in I. Lee, 2002a).

Many linguists classify information in text into given and new (Arnold et. al., 2013). Therefore, a further aspect of textual coherence is information distribution which refers to the presentation of old or known information versus 
new or unknown information (Celce-Murcia \& Olshtain, 2000). Generally, coherent texts often conform to the principle that given or old information precedes the new (I. Lee, 2002b).

The last text-based coherence aspect, as discussed by I. Lee (2002a), is metadiscourse. To I. Lee (2002b), meta-discourse refers to a set of expressions and linguistic devices clarifying writers' attitudes and the organization of information. The existence of meta-discourse markers in texts facilitates comprehension because such markers "help readers organize, interpret, and evaluate information" (I. Lee, 2002b, p. 33). Examples of meta-discourse markers include the logical connectives therefore and but, the sequencers firstly, secondly and finally, the certainty markers definitely and no doubt, and the hedges can and may.

Although the shared knowledge view of reading-writing relationship states that reading and writing are not identical skills, both rely on common knowledge and processes. Reading and writing essentially share similar properties, complement, and enrich each other (Mallett, 2012). Students benefit from the reading and writing activities that go side-by-side (Tsai, 2006). According to Graham and Hebert (2011), instructional material and methods that improve writing skills and processes should improve reading skills and processes as well. In other words, there are many positive relationships between reading and writing including that teaching students of almost all grades how to write improves their reading comprehension (ibid). According to Lubelska (1991), reading contributes to the development of writing skills and vice versa, as illustrated in Figure (1). 
Figure 1. The Relationship between Reading and Writing

\begin{tabular}{|l|l|}
\hline $\begin{array}{l}\text { 1- Read text, identifying } \\
\text { functional value of } \\
\text { sentences (Nuttall, 1982) } \\
\text { and paragraph structure. }\end{array}$ & $\begin{array}{l}\text { 2- Learn to write and practice } \\
\text { writing coherent texts with }\end{array}$ \\
$\begin{array}{l}\text { topic sentence, supporting } \\
\text { sentences, etc. } \\
\text { Moce coherent writing } \\
\text { because of 1-3 in cycle. }\end{array}$ & $\begin{array}{l}\text { 3- Improve understanding } \\
\text { when } \\
\text { reading because of awareness } \\
\text { of how meaning is }\end{array}$ \\
& $\begin{array}{l}\text { communicated } \\
\text { through text structures, links, } \\
\text { etc. }\end{array}$ \\
\hline
\end{tabular}

\section{(Lubelska, 1991, p. 570)}

The cyclical process illustrated in Figure (1) shows that after reading a text and identifying coherence relations, students can adopt some them in their writing, such as generating topic sentences and providing supporting details. Consequently, their reading comprehension skills would improve because of this new textual coherence knowledge. In turn, this would result in improving students' written performance, and so forth.

\section{7-Method}

The study employed the one-group pre-post test design. It is a qusaiexperimental research design in which the same dependant variable is measured in one group of participants before and after administering a treatment (Privitera, 2016).

Participants of this study included 39 year-3 students at Manfalut Secondary School for Girls, which is a public school lying at Manfalut City, Assuit Governorate. Aged between 16 and 17 years and coming from similar socioeconomic background, the participants were selected at random during the 
second semester of the academic year 2016-2017. All of them studied EFL in public schools for 11 years, five lessons per week.

Instruments of the study included Wmatrix 3 , a web-based corpus processing software tool which allows the macroscopic analysis of a text to inform the microscopic one (Rayson 2003). Also, it included: a Reading Comprehension Skills Checklist, an Expository Writing Skills Checklist, a Reading and Writing Skills Pre-Post Test, an Analytic Scoring Rubric and a Student Satisfaction Questionnaire

\section{The Proposed Program}

The overall aim of the program is to enhance third secondary school students' knowledge of textual cohesion and coherence, so as to develop their reading comprehension skills and their ability to write more cohesive and coherent expository essays.

\section{Duration of the Program}

The proposed program lasted for 4 weeks, 5th - 30th March. Each week included three lessons of 90 minutes each (a total of 12 lessons, 18 hours).

\section{Content of the Program}

The program consists of three units with four lessons of ninety minutes each. They aim at enhancing students' knowledge of textual coherence and cohesion so as to improve their reading comprehension and essay writing skills. The first unit covers the skills of identifying and using text structure and genre, the second focuses students' attention on identifying and using textual coherence aspects, whereas the third helps students identify and use textual cohesion features. 


\section{Teaching Aids}

Many visual aids were utilized by the proposed program instructor. Sometimes, the teacher assigned interested students to prepare or bring visuals aids to the classroom. The visual aids used by the teacher included: realia, pictures of places that related to the topics of lessons, diagrams showing text structure, flashcards with new textual cohesion and coherence terminology, picture cards, an overhead projector and a video projector.

\section{Materials and Resources}

Materials of the program were developed after reviewing related literature and many previous studies (Achili, 200; Bechoua, 2012; El-Deen, 2014; I. Lee, 2002a; 2002b; C. Lee 2004; Pichastor, 2005; Williams et al., 2014). Moreover, authentic materials were selected from various websites Reading comprehension and writing lessons were integrated. The main focus of the tasks was on the textual aspects that constituted these texts as identified by I. Lee (2002a). Following is a description of the proposed program.

Table (2)

The Proposed Program Units and Lessons

\begin{tabular}{|c|c|c|c|}
\hline Unit & Skill & Lesson & Title \\
\hline \multirow{4}{*}{1} & \multirow{4}{*}{$\begin{array}{l}\text { Identifying and } \text { Using Text } \\
\text { Features (Genre, Text Type, } \\
\text { Structure, } \\
\text { Paragraphs, Main Ideas, Details) }\end{array}$} & 1 & Water Pollution \\
\hline & & 2 & Sports \\
\hline & & 3 & $\begin{array}{l}\text { Causes of Childhood } \\
\text { Obesity }\end{array}$ \\
\hline & & 4 & $\begin{array}{l}\text { Video Game Addiction } \\
\text { (Revision and Practice) }\end{array}$ \\
\hline \multirow{4}{*}{2} & \multirow{4}{*}{$\begin{array}{lcr}\begin{array}{l}\text { Identifying } \\
\text { Coherence }\end{array} \text { Features } & \text { Textual } \\
\text { (Macro- } \\
\text { structure, } \\
\text { Cohesion, } \\
\text { Distribution, } & \text { Reta-discourse) }\end{array}$} & 1 & Travelling \\
\hline & & 2 & Causes of Happiness \\
\hline & & 3 & $\begin{array}{l}\text { Effects of Excessive Love } \\
\text { of Money }\end{array}$ \\
\hline & & 4 & $\begin{array}{llr}\text { Benefits } & \text { of } & \text { Positive } \\
\text { Thinking } & \text { (Revision and } \\
\text { Practice) } & & \end{array}$ \\
\hline
\end{tabular}




\begin{tabular}{|c|l|c|l|}
\hline 3 & $\begin{array}{l}\text { Identifying and Using Textual } \\
\text { Cohesion Features (Grammatical }\end{array}$ & 1 & $\begin{array}{l}\text { Why Are Cities Becoming } \\
\text { Overcrowded? }\end{array}$ \\
\cline { 3 - 4 } and Lexical Cohesive Devices) & 2 & $\begin{array}{l}\text { Effects of Computer on Our } \\
\text { Lives }\end{array}$ \\
\cline { 3 - 4 } & 3 & $\begin{array}{l}\text { Natural Disasters: Causes } \\
\text { and Effects }\end{array}$ \\
\cline { 3 - 4 } & 4 & $\begin{array}{l}\text { Why Do Many Students } \\
\text { Feel Bored in School? } \\
\text { (Revision and Practice) }\end{array}$ \\
\hline
\end{tabular}

\section{Instructional Procedures}

At the beginning of each unit, the instructor introduced its broad aims. Lesson objectives were discussed with the participants before each lesson. Warming up activities included discussing the content of enlarged pictures and asking for participants' opinions.

The proposed program teacher integrated the deductive and inductive approaches in delivering the lessons. Specifically, the ESA model was adopted as the main instructional methodology. According to Maxom (2014), this model has become popular and it appeals to many teachers. Unlike the PresentationPractice-Production (PPP) model, teachers using the ESA model can move around the stages any time during the lesson. These stages included:

\section{A. Engage}

The instructor attempted to arouse students' interest, emotion and curiosity through showing an amazing enlarged picture or a short video clip when possible. This way, he tried to motivate the students to learn and use the new language or concept.

\section{B. Study}

The participants analyzed reading comprehension texts, highlighting and discussing textual features such as structural patterns, genres, paragraphs and topic sentences. Unlike the PPP model, the teacher did not 
necessarily give presentations. Instead, he often gave students guided activities to help them learn.

\section{Activate}

The participants used the newly-learned items in answering further reading comprehension questions and generating paragraphs and full expository essays.

\section{8- Data Analysis, Results and Discussion}

1-There is a statistically significant difference at (0.01) level between the mean scores of the experimental group on the pre-post test in reading comprehension in favour of the post-test scores.

2-There is a statistically significant difference at $(0.01)$ level between the mean scores of the frequency of cohesive devices adopted in the expository essays written by the experimental group on the pre-post test in favour of the post-test. 3 - There is a statistically significant difference at (0.01) level between the mean scores of the experimental group on the pre-post test in the quality of cohesion established in the expository essays in favour of the post-test scores.

4- There is a statistically significant difference at (0.01) level between the mean scores of the experimental group on the pre-post test in the quality of coherence established in the expository essays in favour of the post-test scores.

5-There is a statistically significant difference at $(0.01)$ level between the mean scores of the experimental group on the pre-post test in the expository essays in favour of the post-test scores.

6- Results of the qualitative analysis indicated that participants' knowledge of textual cohesion and coherence was limited and they experienced many difficulties in using cohesive devices. 


\section{Effect of the Suggested Program}

Table (3) demonstrates the effectiveness of the proposed program in enhancing third-year secondary school students' reading comprehension and writing skills.

Table r.

T-test Results Comparing between the Mean Scores of Participants on the Pre-post Test in Reading Comprehension and Writing Skills

\begin{tabular}{|c|c|c|c|c|c|c|c|c|}
\hline \multicolumn{1}{|c|}{ Test } & N & Mean & $\begin{array}{c}\text { Std. } \\
\text { Deviation }\end{array}$ & $\begin{array}{c}\text { Std. Error } \\
\text { Mean }\end{array}$ & DF & $\begin{array}{c}\text { T- } \\
\text { value }\end{array}$ & Sig & Effect Size \\
\hline Pre -test & 39 & 57.59 & 12.87 & 2.06 & \multirow{2}{*}{38} & 29.87 & 0.01 & 2.06 \\
\hline Post- test & 39 & 87.15 & 14.64 & 2.34 & 38 & \\
\hline
\end{tabular}

As shown in Table (3), there are statistically significant differences at 0.01 level between the mean scores of the participants on the pre-post test in reading comprehension and writing skills in favour of the post- test scores. Moreover, the estimated effect size value (2.06) shown in the table indicates that the program had a large positive effect on the participants' overall skills in reading comprehension and writing skills.

\section{Corpus Analysis of Participants' Written Discourse}

Figure 2 demonstrates the frequency and percentage of cohesive devices (CDs) that the participants' 39 essays included. In all, the participants used 433 CDs in the pre-test essays, classified as: 268 (62\%) grammatical cohesive devices (GCDs) and 165 (38\%) lexical cohesive devices (LCDs).

Figure 2. Frequencies and Percentages of CDs in the Participants' Essays

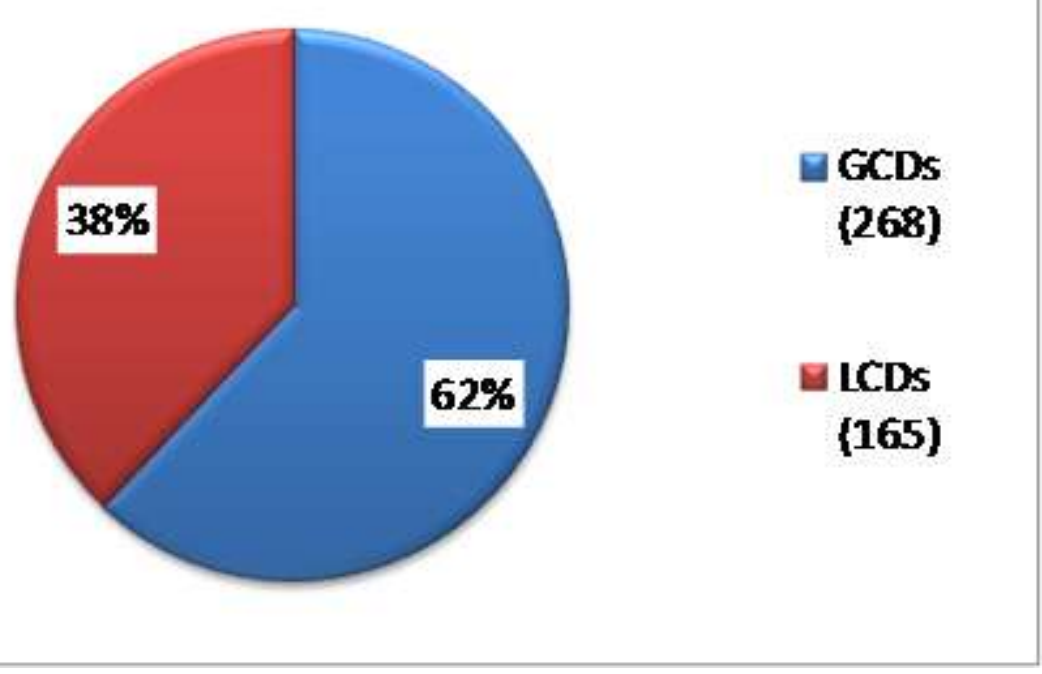




\section{Problems Faced by Participants in Using Cohesive Devices}

Figure (3) displays the percentage of appropriately and inappropriately used devices

Figure (3) Appropriate Vs Inappropriate Use of CDs

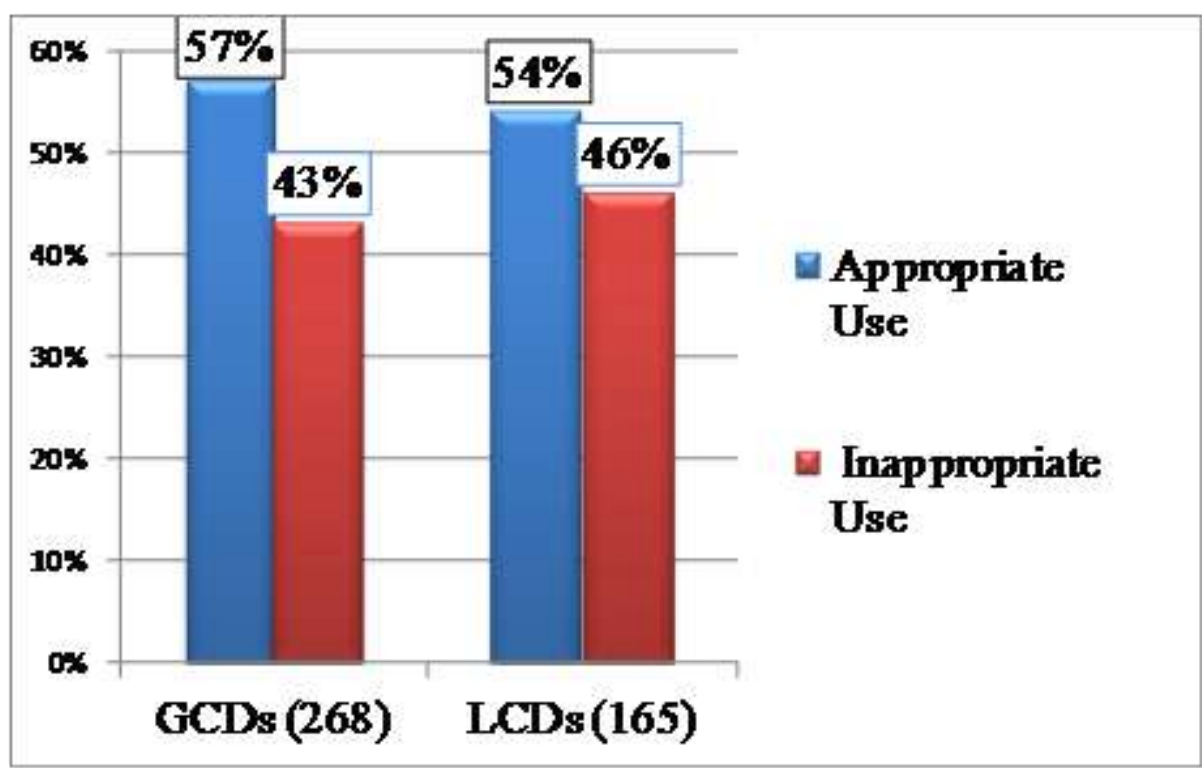

Results illustrated in Figure (3) indicated that the participants made appropriate use of GCDs and LCDs by 57\% and 54\% respectively. However, they faced considerable difficulties in using both, as inappropriate occurrences constituted $43 \%$ of GCDs and $46 \%$ of LCDs.

\section{Conclusions}

-The present study showed that enhancing students' knowledge of textual features, particularly cohesion and coherence, improved their skills in constructing meaning from text. They used this knowledge to recognize the relationships that existed between and among ideas and sentences in text.

-The study also indicated that enhancing students' knowledge of textual features, particularly cohesion and coherence, improved their skills in composing cohesive and coherent expository essays. They employed this knowledge to present, organize and link their ideas in a more logical order. 
- Implicit and explicit teaching of textual cohesion increased students' awareness of cohesive devices. Not only did they get more able to recognize the role that cohesive devices played in reading comprehension texts, but they also did better in employing them in expository writing in terms of quantity and quality.

- Students' awareness of textual coherence aspects, such as macro-structure and meta-discourse, improved. They showed improvement in realizing these aspects in reading comprehension texts and in using them in writing expositions.

- The present study confirmed the teachability and learnability of textual features, particularly cohesion and cohesion. It proved that these two concepts are not too abstract or hard to introduce to secondary school students.

- Contextualization of textual features made them easier to recognize, identify and use. As they were taught in context, textual features got more learnable and usable.

- The present study indicated that when implicit teaching of textual features preceded explicit teaching, it helped the students get more motivated and engaged. Besides, implicit teaching helped students think about and predict the items that they learned.

- Graphic organizers made textual features more teachable and learnable as they were contextualized in integrated reading-writing lessons. They made text structure more visible for teachers to explain and for students to perceive.

- The present study showed that it is feasible to make a cottage industry of textual cohesion and coherence materials to supplement EFL course books which often do not often cover such concepts.

- Using rubrics as teaching tools increased students' motivation and facilitated their understanding of how to compose better expository essays in terms of 
content, text structure, cohesion, coherence and mechanics. Examining criteria of the writing rubric helped them in assessing the quality of their final writing product which became clearer for them.

\section{Pedagogical Implications}

- Textual features, including the concepts of cohesion and coherence, should be first implicitly and then explicitly introduced to secondary school students. More time should be allotted and more efforts should be exerted to expand students' knowledge of such features that help them develop their reading comprehension and writing skills.

- Systematic training courses and workshops on how to teach textual cohesion and coherence in context should be organized for EFL teachers. These courses should point out the importance of these features in text for students as readers and writers.

- The proposed program of the current study can be adopted or infused into secondary school EFL textbooks to deepen students' knowledge of textual features, particularly cohesion and coherence. Students' needs and interests should be taking into consideration when doing so.

- It is advisable that EFL teachers make a cottage industry of textual features, particularly cohesion and coherence, to introduce these features implicitly and explicitly to secondary school students. The current study might be of help for them.

- It is recommended that EFL teachers expand their own knowledge of textual cohesion and coherence through many activities such as extensive and intensive reading, attending training courses and watching tutorial videos about these concepts.

- It is suggested that EFL teachers partially or fully implement the proposed program of the current study. Its content and delivery methods and strategies might be of help to them. However, teachers should take students' needs and interests into account if they decide to do so. 
- Secondary school EFL teachers should conduct corpus-based discourse analyses, using essays and other genres written by their students so as to uncover the textual features within these written production.

- Secondary school students of all English language proficiency levels should seek opportunities to learn textual cohesion and coherence so as to develop their reading comprehension and lengthy writing skills.

- Students should share more responsibilities in learning textual features, with particular focus on cohesion and coherence. They should work independently to find relevant and age-appropriate information about these concepts and learn how to employ them.

- It is recommended that secondary school students read for writing and write for reading, since learning each skill develops the other.

- It is advisable that secondary-stage text book authors embed the concepts of textual cohesion and coherence into integrated reading and writing lessons because knowledge of such concepts has proved to be useful for students as readers and writers.

- Secondary-stage EFL text books should include activities that require students to conduct written discourse analyses of various texts, including some of the essays that they write throughout the academic year. Such analyses could focus on textual aspects, such as text structure, cohesion and coherence.

- Teacher's guidebooks should be provided with textual cohesion and coherence skills checklists and with instructions on how to foster such skills. 


\section{References}

Achili, H. (2007). Teaching Coherence in Writing: The Case of Second Year Students at the University of Mentouri, Constantine. (Doctoral dissertation, University of Mentouri). Retrieved from http://bu.umc.edu.dz/theses/anglais/ACH960.pdf

Alkhawaldeh, A. (2012). The EFL reading comprehension challenges faced by secondary school students in Jordan. European Journal of Social Sciences, 35(2), 140-152. Retrieved from http://www.europeanjournalofsocialsciences.com/

Almasi, J. F., \& Fullerton, S. K. (2012). Teaching strategic processes in reading. ( ${ }^{\text {nd }}$ ed.). New York, USA: Guilford Press.

Arnold, J. E., Kaiser, E., Kahn, J. M., \& Kim, L. K. (2013). Information structure: linguistic, cognitive, and processing approaches. Wiley Interdisciplinary Reviews: Cognitive Science, 4(4), 403-413. $\quad$ http://onlinelibrary.wiley.com/journal/ 10.1002/(ISSN) $\underline{1939-5086}$

Bechoua, S. (2012). Teaching Grammatical cohesive devices to enhance reading comprehension: The case of first year students. ( Unpublished master's thesis) University of Larbi Ben M'hidi, Algeria.

Cain, K. (2010). Reading development and difficulties. West Sussex, UK: BPS Blackwell.

Caswell, R., \& Mahler, B. (2004). Strategies for teaching writing. Alexandria, USA:ASCD.

Celce-Murcia, M., \& Olshtain, E. (2000). Discourse and context in language teaching: A guide for language teachers. Cambridge, UK: Cambridge University Press.

Cho, H. Y., \& Shin, J. A. (2014). Cohesive devices in English writing textbooks and Korean learners' English writings. English Teaching,69(1), 41-59. Retrieved from http://journal.kate.or.kr/?p=46

Cohen, V., \& Cowen, J. (2007). Literacy for children in an information age: Teaching reading, writing, and thinking. Wadsworth, USA: Cengage Learning.

David, M. K. \& Govindasamy, S. (2003). Language education and 'nation building' in multilingual Malaysia. In Bourne, J. \& Reid, E. (Eds.), Language education: World yearbook of education 2003, (pp. 215-226). London, UK: Kogan Page.

El-Deen, A. M. (2014). The effectiveness of an EFL program based on Frerian pedagogy in developing secondary school students' argumentative writing and reflective thinking. (Unpublished doctoral dissertation). Faculty of Education, Ain Shams University. 
El-Koumy, A. S. A. (2006). The effects of the directed reading-thinking activity on EFL students' referential and inferential comprehension. International Journal of Humanities and Social Science, 2 (16), 138-151. Retrieved from http://www. ijhssnet.com/

Ghasemi, M. (2013). An Investigation into the Use of Cohesive Devices in Second Language Writings. Theory and Practice in Language Studies, 3(9), 1615-1623. Retrieved from http://www.academypublication.com/tpls/

Grabe, W. (2009). Reading in a second language: Moving from theory to practice. Cambridge, UK: Cambridge University Press.

Graham, S., \& Hebert, M. (2011). Writing to read: A meta-analysis of the impact of writing and writing instruction on reading. Harvard Educational Review, 81(4), 710-744. Retrieved from http://hepg.org/her-home/home

Graesser, A.C., McNamara, D. S., \& Louwerse, M. M. (2003). What do readers need to learn in order to process coherence relations in narrative and expository text. In Sweet, A. P. \& Snow, C. E. (Eds.), Rethinking Reading Comprehension, (pp. 82-98). New York, USA: Guilford.

Halliday, M. A. K., \& Hasan, R. (1976). Cohesion in English. London, UK: Longman.

Huang, Y. (2012). The Oxford dictionary of pragmatics. Oxford, UK: Oxford University Press.

Hudson, T. (2007). Teaching second language reading. Oxford, UK: Oxford University Press.

Kucan, L., \& Palincsar, A. S. (2013). Comprehension instruction through text-based discussion. Newark, USA: International Reading Association.

Lee, C. C. (2004). Seeing is understanding: Improving coherence in students' writing. The Internet TESL Journal, 10(7). Retrieved from http://iteslj.org/

Lee, I. (2002a). Teaching coherence to ESL students: A classroom inquiry. Journal of second language writing, 11(2), 135-159. Retrieved from https://www.journals.elsevier. com/journal-of-second-language-writing/

Lee, I. (2002b). Helping students develop coherence in writing. Forum, 40 (3), 32-39.

Retrieved from http://exchanges.state.gov/forum/

Lubelska, D. (1991). An Approach to Teaching Cohesion to Improve Reading. Reading in a Foreign Language, 7(2), 569-596. Retrieved from http://nflrc.hawaii.edu/rfl/

Mallett, M. (2012). The primary English encyclopedia: the heart of the curriculum. New York, USA: Routledge. 
Mather, N., Wendling, B. J., \& Roberts, R. (2009). Writing assessment and instruction for students with learning disabilities. West Sussex, UK: John Wiley \& Sons.

Maxom, M. (2014). TEFL lesson plans for dummies. West Sussex, UK: John Wiley \& Sons.

Looney, J, (2008). Teaching, Learning and Assessment for Adults. Improving Foundation Skills. Danvers, USA: OECD.

Pichastor, M. M. (2005). Logical connectors in efl writing: Learners' Use and Instruction. (Unpublished $\mathrm{PhD}$ dissertation). Jaume I University, Spain.

Privitera, G. J. (2016). Research methods for the behavioral sciences. ( $2^{\text {nd }}$ ed.). California, USA: Sage Publications.

Rassouli, M., \& Abbasvandi, M. (2013). The Effects of Explicit Instruction of Grammatical Cohesive Devices on Intermediate Iranian Learners' Writing. European Online Journal of Natural and Social Sciences, 2(2s),15-27. Retrieved from http:// european-science.com/eojnss

Rayson, P. (2003). Matrix: A statistical method and software tool for linguistic analysis through corpus comparison (Unpublished doctoral dissertation) Lancaster University, UK.

Richards, J. C., \& Renandya, W. A. (Eds.). (2002). Methodology in language teaching: An anthology of current practice. Cambridge, UK: Cambridge University Press.

Richards, J. C., \& Schmidt, R. W. (2013). Longman dictionary of language teaching and applied linguistics. New York, USA: Routledge.

Sabet, A. F., Khodabandehlou, M. \& Jahandar, S. (2013). The Impact of instructing discourse markers (cohesive devices) on Iranian EFL learners' reading comprehension ability. Indian Journal of Fundamental and Applied Life Sciences, 3 (3), 273-280 . Retrieved from http://www.cibtech.org/jls.htm

Snow, C. (2002). Reading for Understanding. Towards an $R \& D$ Program in Reading Comprehension. Santa Monika, USA: RAND.

Strazny, P. (Ed.). (2013). Encyclopedia of linguistics. New York, USA: Routledge.

Tangkiengsirisin, S. (2010). Promoting cohesion in EFL expository writing: A Study of graduate students in Thailand. International Journal of Arts and Sciences, 3 (16), 1-34. Retrieved from https://www.internationaljournal.org/

Tsai, J. M. (2006). Connecting reading and writing in college EFL courses. The Internet TESL Journal, 12(12). Retrieved from http://iteslj.org/ 
Williams, J. P., Pollini, S., Nubla-Kung, A. M., Snyder, A. E., Garcia, A., Ordynans, J. G., \& Atkins, J. G. (2014). An intervention to improve comprehension of cause/effect through expository text structure instruction. Journal of Educational Psychology, 106(1), 1-17. Retrieved from http://www.apa.org/pubs/journals/edu/ 